\title{
Travel Patterns in China
}

\section{Questionnaires}

Tini Garske ${ }^{1+*}$, Hongjie $\mathrm{Yu}^{2^{*}}$, Zhibin Peng ${ }^{2}$, Min Ye ${ }^{2}$, Hang Zhou ${ }^{2}$, Xiaowen Cheng ${ }^{3}$, Jiabing Wu $^{4}$, Neil Ferguson ${ }^{1}$

${ }^{1}$ MRC Centre of Outbreak Analysis and Modelling, Imperial College London

${ }^{2}$ Office for Disease Control and Emergency Response, Chinese Center for Disease Control and Prevention (China CDC), Beijing, China

${ }^{3}$ Department of Communicable Disease Prevention and Control, Shenzhen Center for Disease Control and Prevention, Shenzhen, China

${ }^{4}$ Department of Communicable Disease Prevention and Control, Anhui Provincial Centers for Disease Control and Prevention, Hefei, China

†'Email: t.garske@imperial.ac.uk

${ }^{*}$ Contributed equally 


\section{Registration form (resident traveling survey)}

__Prefecture___District/County__Community/ factory /village Association Page :

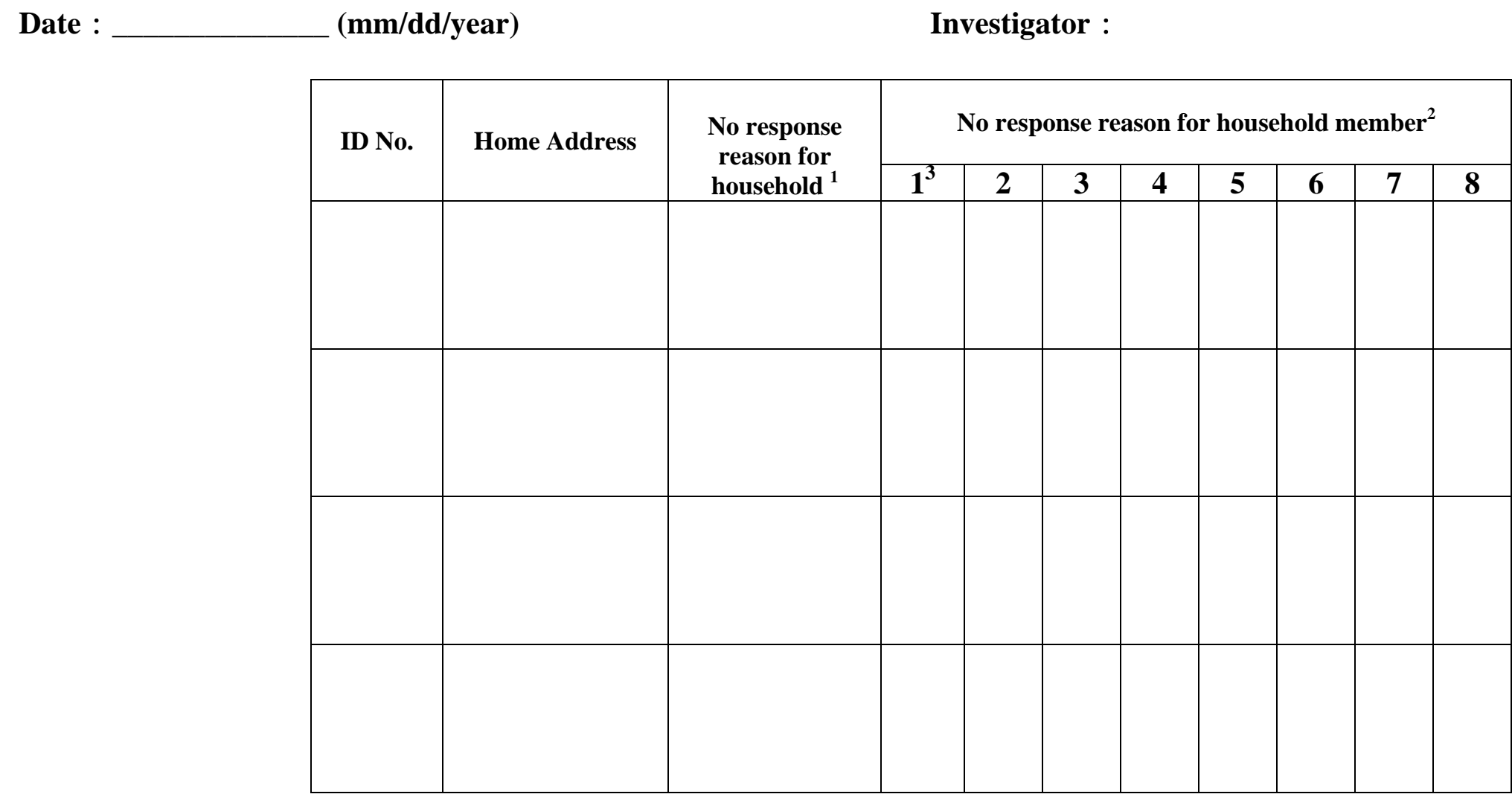

Note:

1. (1) Nobody at home, (2) Refuse to participate, (3) Other (if choose (3), please write down the reason directly in the blank)

2. (1) Refuse to participate, (2) Other (if choose (2), please write down the reason directly in the blank)

3. The Arabic numerals are ID No. for each family member, which must be consistent with that in the questionnaire. 


\section{Questionnaire ---- Shenzhen}

\section{Resident Traveling Survey}

\section{Good morning/afternoon/evening !}

With the spread of H5N1, potential next pandemic will be a terrible threat to human beings. It is necessary for us to develop feasible and effective pandemic preparedness and response strategy. The resident traveling survey is implemented by Chinese Center for Disease Control and Prevention. The purpose of the survey is to learn about the residents' traveling habits through collecting individual traveling data (including the distance from home to work/school and other traveling within past 7 days) to provide scientific evidence for establishing pandemic modeling and developing the strategy of pandemic influenza preparedness and response in China.

We mainly collect the information about your everyday traveling such as going to work or school and other traveling within past 7 days. Simple demographic data such as gender and age will also be collected. There are not any sensitive or private questions in the questionnaire, so you will not feel any discomforts. Meanwhile we will not begin the face to face survey until obtain oral informed consent from you. We promise that all the information you provide will be kept secret strictly. You will be voluntary for the survey. If you are not willing to take part in our survey, it would not bring any bad impact for you. It will take you less than 10 minutes to finish the survey, we feel sorry for bothering you. If you have any question, please consult our investigators, we will try our best to explain for you.

If you consent to participate, let's begin the survey. Please answer all the questions truthfully. We really appreciate you for your kindly help. Thank you very much!

Sincerely
Verbal informed consent
(1)yes, (2)no
Date:
$(\mathrm{mm} / \mathrm{dd} /$ year $)$ 


\section{Chinese Center for Disease Control and Prevention}

2007-7

\section{Resident Traveling Survey Questionnaire ID Number :}

\section{Investigator:}

Checker:
Interview Date: (mm/dd/year)

Check Date: ( $\mathrm{mm} / \mathrm{dd} /$ year)

\begin{tabular}{|c|c|c|c|c|c|c|c|c|c|c|}
\hline \multicolumn{2}{|c|}{ Home Address: } & Shen & en Prefe & cture & istrict___ $\mathbf{T}$ & Nnship_ & \multicolumn{4}{|c|}{ Community } \\
\hline \multicolumn{11}{|c|}{ Section One Distance travel to workplace/school } \\
\hline No. ${ }^{1}$ & Age & Sex & $\underset{2}{\text { Vocation }}$ & $\begin{array}{c}\text { Household } \\
\text { Registry }^{3}\end{array}$ & Dormitory ${ }^{4}$ & $\begin{array}{c}\text { GPS } \\
\text { Distance } \\
\text { (km) }\end{array}$ & $\begin{array}{c}\text { Estimated } \\
\text { Distance }^{5} \\
\quad(\mathbf{k m})\end{array}$ & $\begin{array}{c}\text { out of } \\
\text { mainland } \\
\text { China }^{6}\end{array}$ & $\begin{array}{c}\text { All other travel outside of local area in } \\
\text { the last } 7 \text { days }^{7}\end{array}$ & comment \\
\hline \multicolumn{11}{|l|}{1} \\
\hline \multicolumn{11}{|l|}{2} \\
\hline \multicolumn{11}{|l|}{3} \\
\hline \multicolumn{11}{|l|}{4} \\
\hline \multicolumn{11}{|l|}{5} \\
\hline \multicolumn{11}{|l|}{6} \\
\hline \multicolumn{11}{|l|}{7} \\
\hline 8 & & & & & & & & & & \\
\hline
\end{tabular}

Note :

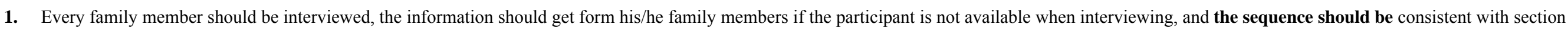
two.

2. (1)student (2)working (3)non-working

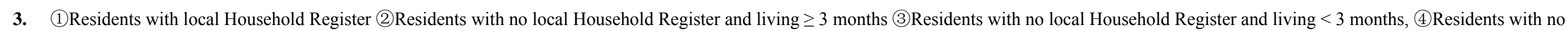
local Household Register and living $<2$ months, (5)Residents with no local Household Register and living $<1$ months. 
4. If the interviewee lived in the factory dormitories, please mark " $\vee$ " in the blank.

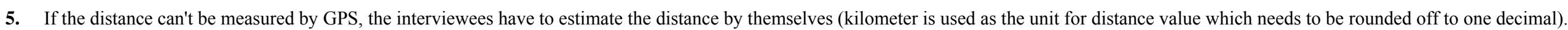

6. If the interviewee's workplace or school is located out of mainland China, please fill the location in the blank (HK SAR, Macao etc).

7. If the interviewee has other travel outside of local area in the last 7 days, please mark " ل" in the blank. (Shenzhen : the journey out of Shenzhen)

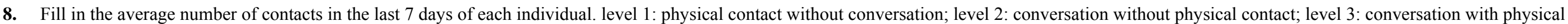
contact. 


\begin{tabular}{|c|c|c|c|c|c|c|c|c|c|c|c|}
\hline \multicolumn{12}{|c|}{ Section Two All other travel outside of local area in the last 7 days ${ }^{1}$} \\
\hline \multirow{4}{*}{ No. $^{2}$} & \multirow{4}{*}{ Times } & \multicolumn{6}{|c|}{ National } & \multicolumn{4}{|c|}{ International } \\
\hline & & \multicolumn{2}{|c|}{ Destination $^{3}$} & \multirow{3}{*}{$\begin{array}{c}\text { GPS } \\
\text { Distance }^{4} \\
(\mathbf{k m})\end{array}$} & \multirow{3}{*}{$\begin{array}{c}\text { Urban } \\
\text { To } \\
\text { rural }^{5}\end{array}$} & \multirow{3}{*}{$\begin{array}{c}\text { Rural } \\
\text { to } \\
\text { urban }^{5}\end{array}$} & \multirow{3}{*}{$\begin{array}{l}\text { Travel } \\
\text { Reason }^{6}\end{array}$} & \multicolumn{2}{|r|}{ Destination $^{3}$} & \multirow{3}{*}{$\begin{array}{c}\text { Distance }^{7} \\
\text { (km) }\end{array}$} & \multirow{3}{*}{$\begin{array}{l}\text { Travel } \\
\text { Reason }\end{array}$} \\
\hline & & __Province & & & & & & \multirow{2}{*}{$\begin{array}{c}\text { HK } \\
\text { \&Macao }^{5} \\
\end{array}$} & \multirow{2}{*}{$\begin{array}{c}\text { Other }^{5} \\
\text { Country_Province }\end{array}$} & & \\
\hline & & Prefecture & District/County & & & & & & & & \\
\hline & (1) & & & & & & & & & & \\
\hline & (2) & & & & & & & & & & \\
\hline & (3) & & & & & & & & & & \\
\hline & (1) & & & & & & & & & & \\
\hline & (2) & & & & & & & & & & \\
\hline & (3) & & & & & & & & & & \\
\hline & (1) & & & & & & & & & & \\
\hline & (2) & & & & & & & & & & \\
\hline & (3) & & & & & & & & & & \\
\hline & (1) & & & & & & & & & & \\
\hline & (2) & & & & & & & & & & \\
\hline & (3) & & & & & & & & & & \\
\hline & (1) & & & & & & & & & & \\
\hline & (2) & & & & & & & & & & \\
\hline & (3) & & & & & & & & & & \\
\hline
\end{tabular}

Note :

1. This part is set aside only for the interviewees who has other travel outside of local area in the last 7 days.

2. Fill the ID No. of the interviewees who has journeys caused by non-work/non-school in the last 7 days. and the sequence should be consistent with section one.

3. If the destinations are more than one place, please fill all the destinations in the blank.

4. If the destinations are more than one place, please fill all the GPS distance in the blank. 


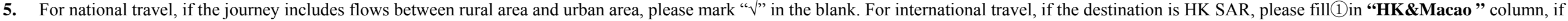

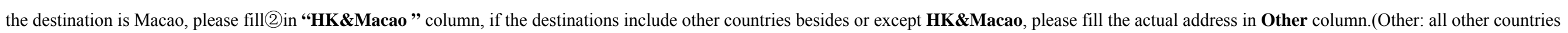
except HK SAR and mainland China).

6. (1)Business (2)Tour (3)Visit relatives and friends (4)Other (If choose (4), write down travel reason directly in the blank).

7. Don't need to fill. 


\section{Questionnaire ---- Huangshan}

\section{Resident Traveling Survey}

\section{Good morning/afternoon/evening !}

With the spread of H5N1, potential next pandemic will be a terrible threat to human beings. It is necessary for us to develop feasible and effective pandemic preparedness and response strategy. The resident traveling survey is implemented by Chinese Center for Disease Control and Prevention. The purpose of the survey is to learn about the residents' traveling habits through collecting individual traveling data (including the distance from home to work/school and other traveling within past 7 days) to provide scientific evidence for establishing pandemic modeling and developing the strategy of pandemic influenza preparedness and response in China.

We mainly collect the information about your everyday traveling such as going to work or school and other traveling within past 7 days. Simple demographic data such as gender and age will also be collected. There are not any sensitive or private questions in the questionnaire, so you will not feel any discomforts. Meanwhile we will not begin the face to face survey until obtain oral informed consent from you. We promise that all the information you provide will be kept secret strictly. You will be voluntary for the survey. If you are not willing to take part in our survey, it would not bring any bad impact for you. It will take you less than 10 minutes to finish the survey, we feel sorry for bothering you. If you have any question, please consult our investigators, we will try our best to explain for you.

If you consent to participate, let's begin the survey. Please answer all the questions faithfully. We really appreciate you for your kindly help. Thank you very much!

Sincerely

Verbal informed consent (1)yes, (2)no
Date: (mm/dd/year) 


\section{Chinese Center for Disease Control and Prevention}

2007-7

\section{Resident Traveling Survey Questionnaire ID Number:}

Investigator:

Interview Date:

(mm/dd/year)

Checker:

Check Date:

(mm/dd/year)

\begin{tabular}{|c|c|c|c|c|c|c|c|}
\hline \multicolumn{2}{|c|}{$\begin{array}{l}\text { HomeAddress: } \\
\text { Street/Road }\end{array}$} & ngshe & refecture & \multicolumn{2}{|c|}{ District/County } & \multicolumn{2}{|c|}{ _Township___Community/ Village } \\
\hline \multicolumn{8}{|c|}{ Section One Distance travel to workplace/school } \\
\hline No. ${ }^{1}$ & Age & Sex & Vocation $^{2}$ & $\begin{array}{r}\text { Household } \\
\text { Registry }^{3}\end{array}$ & $\begin{array}{c}\text { Estimated } \\
\text { Distance }(\mathbf{k m})^{4}\end{array}$ & $\begin{array}{l}\text { All other travel outside of } \\
\text { local area in the last } 7 \text { days }^{5}\end{array}$ & Comment \\
\hline \multicolumn{8}{|l|}{1} \\
\hline \multicolumn{8}{|l|}{2} \\
\hline \multicolumn{8}{|l|}{3} \\
\hline \multicolumn{8}{|l|}{4} \\
\hline \multicolumn{8}{|l|}{5} \\
\hline \multicolumn{8}{|l|}{6} \\
\hline \multicolumn{8}{|l|}{7} \\
\hline 8 & & & & & & & \\
\hline
\end{tabular}

Note:

1. Every family member should be interviewed, the information should get form his/he family members if the participant is not available when interviewing, and the sequence should be consistent with section two. 
2. (1) student, (2) working, (3) non-working

3. (1) Residents with local Household Register, (2) residents with no local Household Register and living $\geq 3$ months, (3) residents with no local Household Register and living $<3$ months, (4) Residents with no local Household Register and living $<2$ months, (5) Residents with no local Household Register and living $<1$ months.

4. Estimated by the interviewees themselves, kilometer is used as the unit for distance value which needs to be rounded off to one decimal.

5. If the interviewee has other travel outside of local area, please mark " $\sqrt{ }$ " in the blank. (Tunxi District: the journey out of Tunxi District, Xiuning County: the journey out of Xiuning County). 


\begin{tabular}{|c|c|c|c|c|c|c|c|c|c|c|c|}
\hline \multicolumn{12}{|c|}{ Section Two All other travel outside of local area in the last 7 days 1} \\
\hline \multirow{4}{*}{ No. $^{2}$} & \multirow{4}{*}{ Times } & \multicolumn{6}{|c|}{ National } & \multicolumn{4}{|c|}{ International } \\
\hline & & \multirow{3}{*}{\multicolumn{2}{|c|}{\begin{tabular}{l}
\multicolumn{2}{c}{ Destination $^{3}$} \\
_Province \\
Prefecture__ District/County
\end{tabular}}} & \multirow{3}{*}{$\begin{array}{c}\text { GPS } \\
\text { Distance }^{4} \\
\text { (km) }\end{array}$} & \multirow{3}{*}{$\begin{array}{l}\text { Urban } \\
\text { To } \\
\text { rural }^{5}\end{array}$} & \multirow{3}{*}{$\begin{array}{c}\text { Rural } \\
\text { to } \\
\text { urban }^{5}\end{array}$} & \multirow{3}{*}{$\begin{array}{c}\text { Travel } \\
\text { Reason }^{6}\end{array}$} & \multicolumn{2}{|r|}{ Destination $^{3}$} & \multirow{3}{*}{$\begin{array}{c}\text { Distance }^{4} \\
(\mathbf{k m})\end{array}$} & \multirow{3}{*}{$\begin{array}{l}\text { Travel } \\
\text { Reason }\end{array}$} \\
\hline & & & & & & & & \multirow{2}{*}{$\begin{array}{c}\text { HK } \\
\text { \&Macao }^{5} \\
\end{array}$} & \multirow{2}{*}{$\begin{array}{c}\text { Other }^{5} \\
\text { Country_Province }\end{array}$} & & \\
\hline & & & & & & & & & & & \\
\hline & (1) & & & & & & & & & & \\
\hline & (2) & & & & & & & & & & \\
\hline & (3) & & & & & & & & & & \\
\hline & (1) & & & & & & & & & & \\
\hline & (2) & & & & & & & & & & \\
\hline & (3) & & & & & & & & & & \\
\hline & (1) & & & & & & & & & & \\
\hline & (2) & & & & & & & & & & \\
\hline & (3) & & & & & & & & & & \\
\hline & (1) & & & & & & & & & & \\
\hline & (2) & & & & & & & & & & \\
\hline & (3) & & & & & & & & & & \\
\hline & (1) & & & & & & & & & & \\
\hline & (2) & & & & & & & & & & \\
\hline & (3) & & & & & & & & & & \\
\hline
\end{tabular}

Note:

1. This part is set aside only for the interviewees who has other travel outside of local area in the last 7 days.

2. Fill the ID No. of the interviewees who has their travel outside of local area in the last 7 days. and the sequence should be consistent with section one.

3. If the destinations are more than one place, please fill all the destinations in the blank.

4. Don't need to fill. 


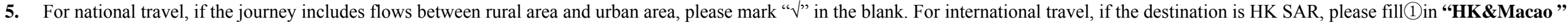

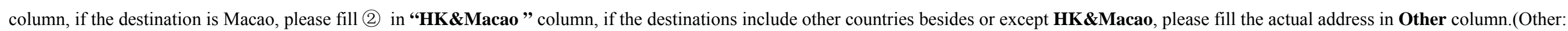
all other countries except HK SAR and mainland China).

6. (1) Business, (2) Tour, (3) Visit relatives and friends, (4) Other (If choose (4), write down travel reason directly in the blank) 